Volume 2 Issue 1, Juni 2020

http://ejournal.unsub.ac.id/index.php/publik

\title{
KINERJA UNIT PELAYANAN TEKNIS DAERAH RUMAH POTONG HEWAN
}

\author{
Iwan Henri Kusnadi ${ }^{1}$ \\ Fakultas Ilmu Administrasi Universitas Subang \\ iwanhenri01@gmail.com
}

\author{
Ade Suparman ${ }^{2}$ \\ Fakultas Ilmu Administrasi Universitas Subang \\ suparmanade09@gmail.com
}

\begin{abstract}
Abstrak
Penelitian ini mengkaji dan menganalisa mengenai bagaimana Kinerja UPTD Rumah Potong Hewan (RPH) Subang pada DInas Peternakan dan Kesehatan Hewan Kabupaten Subang dan factor-faktor apa saja yang menghambat pencapaian Kinerja UPTD Rumah Potong Hewan (RPH) Subang pada Dinas Peternakan dan Kesehatan Hewan Kabupaten Subang. Pendekatan penelitian yang digunakan adalah pendekatan kualitatif yaitu prosedur penelitian yang menggambarkan fakta-fakta dan menjelaskan objek penelitian serta menggali informasi yang dibutuhkan sesuai dengan kenyataan sebagaimana adanya. Hasil penelitian memberikan gambaran bahwa 1) Tujuannya adalah memberikan pelayanan yang terbaik bagi masyarakat penggunma jasa RPH dengan memperbaiki prosedur yang ada serta memperbaiki pelayanan pemotongan dan unit pengoahan daging. 2) Rumah Potong Hewan Subang diperlukan untuk pelayanan kepada masyarakat dalam penyediaan daging sehat yang sesuai dengan perkembangan yang terjadi. 3) Umpan balik terhadap pelayanan kepada berguna jasa Rumah Potong Hewan (RPH) masih kurang memuaskan bagi pengguna jasa. 4) UPTD Rumah Potong Hewan Subang Dinas Peternakan dan Kesehatan Hewan Kabupaten Subang belum dilengkapi dengan peralatan dan perlengkapan yang sesuai dengan standard yang ditetapkan oleh Kementerian Pertanian dikarenakan masih kurangnya anggaran dari Pemerintah Daerah. 5) Kompetensi Pegawai di UPTD Rumah Potong Hewan (RPH) Subang Dinas Peternakan dan Kesehatan Hewan Kabupaten Subang masih perlu ditingkatkan seiring dengan perkembangan yang terus berkembang dikarenakan latar belakang pendidikan yang mereka miliki bukan dari dokter hewan. 6) Rumah Potong Hewan (RPH) untuk dapat meningkatkan motivasi kerja anggotanya berupaya memberikan tanggungjawab karena merupakan kesanggupan seseorang untuk menyelesaikan pekerjaan yang diserahkan kepar, ra dengan baik, tepat waktu serta berani mengambil resiko atas keputusan yang diambilnya atau tindakan yang dilakukannya. 7) Kebutuhan daging yang tidak mampu dipenuhi oleh Rumah Potong Hewan yang
\end{abstract}




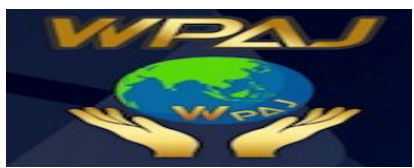

Volume 2 Issue 1, Juni 2020

http://ejournal.unsub.ac.id/index.php/publik

dikarenakan adanya penurunan jumlah sapi yang dipotong dari 10 sampai dengan 15 ekor per hari berkurang menjadi hanya 5 sampai dengan 8 ekor saja setiap harinya.

Kata Kunci : Kinerja, UPTD Rumah Potong Hewan Subang

\begin{abstract}
This study examines and analyzes the performance of the Subang Slaughterhouse UPTD in Subang Regency's Livestock and Animal Health Service and what factors hinder the achievement of the Subang Slaughterhouse UPTD Performance at the Subang District Animal Husbandry and Animal Health Service. The research approach used to study the performance of the Subang Slaughterhouse UPTD at the Subang Regency Animal Husbandry and Animal Health Service is a qualitative approach, which is a research procedure that describes the facts and explains the object of research and digs up the information needed in accordance with reality as it is. The results of the study illustrate that 1) The goal is to provide the best service to the community using RPH services by improving existing procedures and improving slaughtering services and meat processing units. 2) Subang Slaughterhouse is needed for services to the community in the supply of healthy meat in accordance with the developments that occur. 3) Feedback on services to useful slaughterhouse services (RPH) is still unsatisfactory for service users. 4) Subang Animal Husbandry Unit UPTD Subang District Animal Husbandry and Health Office has not been equipped with equipment and equipment in accordance with the standards set by the Ministry of Agriculture due to lack of budget from the Regional Government. 5) Employee Competency in Subang Sub-Province Slaughterhouse (UPH) Subang Animal Husbandry and Animal Health Office still needs to be improved along with the development that continues to grow because their educational background is not from veterinarians. 6) Abattoirs (RPH) to be able to increase the work motivation of members trying to give responsibility because it is a person's ability to complete the work submitted to him properly, on time and dare to take risks on the decisions he takes or the actions he does. 7) Meat needs that cannot be fulfilled by Abattoirs due to a decrease in the number of cattle slaughtered from 10 to 15 per day are reduced to only 5 to 8 per day.
\end{abstract}

Keywords: Performance, UPTD Subang Slaughterhouse

\title{
Pendahuluan
}

Daging merupakan bahan pangan asal ternak yang dibutuhkan oleh manusia karena memiliki nilai gizi yang tinggi serta mengandung asam amino esensial yang diperlukan untuk pertumbuhan sel-sel baru, pengganti sel-sel rusak serta diperlukan bagi metabolisme tubuh. Sebagai bahan pangan bagi masyarakat aspek kuantitatif, aspek nilai gizi, aspek kesehatan dan aspek kehalalan merupakan prasyarat bagi kualitas dan keamanan daging yang wajib dipenuhi. Salah satu tahap yang sangat menentukan kualitas dan keamanan daging dalam mata rantai penyediaan daging adalah tahap "pemotongan" di Rumah Pemotongan Hewan ( RPH ). Pada tahap ini 


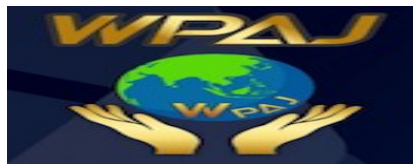

Volume 2 Issue 1, Juni 2020

http://ejournal.unsub.ac.id/index.php/publik

terjadi perubahan dari otot ( Hewan Hidup) ke daging melalui proses penyembelihan. Pencemaran microorganisme terhadap daging pada proses pengeluaran jeroan ( eviserasi ) bisa terjadi akibat penanganan hewan dan daging di $\mathrm{RPH}$ yang kurang baik maupun tidak higienis yang selanjutnya dapat berdampak terhadap kehalalan,mutu dan keamanan daging yang dihasilkan. Penerapan sistem jaminan mutu dan keamanan pangan di Rumah Pemotongan Hewan ( RPH ) sangatlah penting karena dapat menjamin produk yang akan dipasarkan berkualitas dan terjamin kesehatanya sehingga masyarakatpun merasa lebih aman dan terlindungi.

Dari data Dinas Peternakan dan Kesehatan Kabupaten Subang, Kabupaten Subang setiap bulan rata-rata kebutuhan konsumsi daging sapi oleh masyarakat mencapai 132,7 ton atau setara dengan 456 ekor sapi. Dari kebutuhan daging tersebut hanya 27 persen yang bisa dipenuhi peternak lokal sedangkan 73 persennnya ngambil dari peternak diluar Kabupaten Subang yang mayoritas dari daerah jawa tengah dan jawa timur.

Rumah Potong Hewan Kabupaten Subang sudah berdirisejak tahun 1996 dan dalam menjalankan tugas dan fungsinya Rumah Potong Hewan Kabupaten Subang belum didukung oleh sarana dan prasarana yang memadai dan belum sesuai dengan standard yang ditentukan oleh Surat Keputusan Menteri Pertanian Nomor 555/Kpts/TN.240/0/1986 tentang syarat-syarat Rumah Potong Hewan yang terdiri dari prasyaratan lokasi , sarana bangunan dan tata letak, peralatan, hygiene karyawan dan perusahaan, pengawasan masyarakat veteriner, kendaraan pengangkut daging, ruang pendingin atau pelayuan, ruang pembeku, ruang pembagian karkas dan pengemasan daging serta laboratorium.

umah Potong Hewan (RPH) Kabupaten Subang, merupakan Unit Pelaksana Teknis Dinas (UPTD) yang berada dibawah naungan Dinas Peternakan dan Kesehatan Hewan Kabupaten Subang berdasarkan Peraturan Bupati Subang nomor 14G13 tahun 2008 tentang Tugas Pokok dan Fungsi Unit Pelaksana Teknis Dinas Rumah Potong Hewan Dinas Peternakan Kabupaten Subang. RPH sebagai unit pelayanan publik memeiliki fungsi teknis, ekonomis dan sosial dimana dalam melaksanakan tugasnya mengacu pada visi dan misi Dinas Peternakan dan Kesehatan Hewan Kabupaten Subang. RPH Kabupaten Subang direncanakan memiliki konsep terpadu dimana $\mathrm{RPH}$ tidak hanya memberikan pelayanan tapi juga dapat melakukan pengolahan daging.

Rumah Potong Hewan ( $\mathrm{RPH}$ ) merupakan sarana yang dibangun oleh Pemerintah Daerah Kabupaten Subang untuk masyarakat khusunya untuk pengguna jasa pemotongan hewan yang diharapkan bisa memberikan pelayanan yang baik dikarenakan apabila mempunyai pelayanan yang baik maka diharapkan tidak ada lagi masyarakat yang melakukan pemotongan hewan diluar Rumah Potong Hewan ( $\mathrm{RPH}$ ) yang telah disediakan oleh Pemerintah Daerah Kabupaten Subang, sehingga semua daging yang akan beredar ke pasaran terlebih dahulu melalui kontrol yang ketat dari Dinas Peternakan dan Kesehatan Hewan Kabupaten Subang lewat Rumah Potong Hewan ( RPH ) dengan mengacu kepada standard yang ada. Pengawasan penjualan daging dan mengetahui asal usul daging yang diperjualbelikan baik daging lokal maupun daging impor serta melihat tanggal produksi yang tertera di box 
kemasan daging serta tanggal kadaluarsa dan memeriksa kelayakan daging dan kualitas daging baik sapi maupun daging unggas yang dijual dipasar yang ada di Kabupaten Subang untuk menghindari daging bangkai, daging gelonggongan dan daging berpengawet merupakan rutinitas yang selalu dilaksanakan oleh UPTD Rumah Potong Hewan Kabupaten Subang didalam menjaga keamanan produk asal hewan terhadap masyarakat Kabupaten Subang.

Mengingat beberapa permasalahan tersebut diatas maka setiap kegiatan yang bergerak dan berhubungan dengan penanganan daging harus dilaksanakan dengan memenuhi persyaratan kesehatan masyarakat veteriner. Sehingga masyarakat konsumen daging akan dapat memperoleh manfaat dan nilai kelebihan akan gijinya serta sekaligus dapat terhindar dari penularan penyakit zonosis. Diharapkan dengan adanya RPH terpadu dapat memberikan pelayanan yang berkualitas dengan berorientasi kepada kebutuhan dan kepuasan masyarakat.

enulis melakukan penelitian mengenai Kinerja Unit Pelayanan Teknis Daerah Rumah Potong Hewan ( RPH ) Dinas Peternakan dan Kesehatan Hewan Kabupaten Subang yang menurut penulis belum optimal dengan indikator permasalahan sebagai berikut:

1. Berdasarkan sumber dari Dinas Peternakan dan Kesehatan Hewan Kabupaten Subang dari 6 ( enam ) orang pegawai yang dibutuhkan khususnya juru sembelih yang mempunyai sertifikat juru sembelih halal hanya ada 3 (tiga ) orang saja sehingga seringkali bila jumlah hewan yang akan dipotong jumlahnya meningkat tidak bisa dilayani semuanya, sehingga banyak masyarakat pengguna jasa RPH milik Pemerintah Daerah Kabupaten Subang beralih ke RPH non Pemerintah yang tidak memiliki Surat Keterangan Kesehatan Pangan Asal Hewan ( SKKPAH ) dari Dinas Peternakan dan Kesehatan Hewan Kabupaten Subang dan mengakibatkan sulitnya mengontrol kesehatan daging yang akan beredar kepasaran.

2. Dari target 5400 ekor sapi per tahun RPH hanya mampu memotong 2880 ekor saja atau sekitar 53 \% atau yang biasanya RPH dapat memotong 10 s/d 15 ekor perhari sekarang hanya memotong $5 \mathrm{~s} / \mathrm{d} 8$ ekor saja perhari.

3. Sarana dan prasarana UPTD Rumah Potong Hewan ( RPH ) Dinas Peternakan dan Kesehatan Hewan Kabupaten Subang yang belum sesuai dengan Surat Keputusan Menteri Pertanian Nomor 555/Kpts/TN.240/0/1986 tentang syaratsyarat Rumah Potong Hewan.

\section{Kerangka Teori}

\section{a. Kinerja}

Kinerja sudah menjadi kata populer yang sangat menarik dalam pembicaraan manajement publik. Konsep kinerja pada dasarnya dapat dilihat dari dua segi yaitu kinerja pegawai ( perindividu) dan kinerja organisasi. Kinerja adalah gambaran mengenai tingkat pencapaian pelaksanaan tugas dalam suatu organisasi dalam upaya mewujudkan sasaran, tujuan, visi dan misi organisasi tersebut (Bastian, 2006:274 )

Konsep kinerja dapat didefinisikan sebagai sebuah pencapaian hasil ( Rue dan byars, 1981 dalam keban 2005 : 59 ). Hal ini berarti bahwa kinerja suatu organisasi itu 
dapat dilihat dari tingkatan sejauh mana organisasi dapat mencapai tujuan yang didasarkan pada tujuan yang sudah ditetapkan sebelumnya. Kinerja merupakan hasil dari kegiatan kerjasama diantara anggota atau komponen organisasi dalam rangka mewujudkan tujuan organisasi. Sederhananya kinerja merupakan produk dari kegiatan administrasi yaitu kegiatan kerjasama dalam sebuah organisasi atau kelompok untuk mencapai tujuan yang pengelolaannya biasa disebut dengan manajement.

inerja dikatakan sebuah hasil ( output)dari suatu proses tertentu yang dilakukan oleh seluruh komponen organisasi terhadap sumber-sumber tertentu yang digunakan ( input ). Selanjutnya kinerja juga merupakan hasil dari serangkaian proses kegiatan yang dilakukan untuk mencapai tujuan tertentu sebuah organisasi. Dalam kerangka organisasi terdapat hubungan anatara kinerja perorangan (Individual Performance )dengan kinerja organisasi ( Organization Performance). Organisasi pemerintah maupun swasta besar maupun kecil dalam mencapai tujuan yang telah ditetapkan harus melalui kegiatan - kegiatan yang digerakan oleh orang atau sekelompok orang yang aktif berperan sebagai pelaku dengan kata lain tercapainya tujuan organisasi hanya dimungkinkan karena adanya upaya yang dilakukan oleh orang dalam organisasi tersebut.

Pernyataan Smith yang dikutip oleh Sedarmayanti ( 2001 : 50 ) Mengungkapkan bahwa: "...output drive from processes, human or otherwise", jadi dikatakannya bahwa kinerja merupakan hasil atau keluaran dari suatu proses. kinerja merupakan hasil dari suatu proses.Sedangkan menurut Efendy ( 2002 : 194 ) mengatakan bahwa: Kinerja adalah unjuk kerja yang merupakan hasil kerja yang dihasilkan oleh pegawai atau prilaku nyata yang ditampilkan sesuai dengan perannya dalam organisasi. Definisi kinerja diatas menjelaskan gambaran mengenai tingkat pencapaian pelaksanaan tugas yang dilakukan oleh seluruh pegawai yang ada disuatu organisasi atau instansi pemerintah. Meningkatkan kinerja dalam sebuah organisasi atau instansi pemerintah merupakan tujuan atau target yang ingin dicapai oleh organisasi dan instansi pemerintah dalam memaksimalkan suatu kegiatan.

\section{b. Ruang Lingkup Manajemen Kinerja}

Manajemen kinerja sebenarnya mempuyai ruang lingkup yang lebih besar. Bila program ini diterapkan ia bersifat menyeluruh atau menggarap semua bagian atau fungsi dari sebuah organisasi. Program ini akan menjamah semua elemen, unsur atau input yang harus didayagunakan oleh organisasi untuk meningkatkan kinerja organisasi tersebut bukan hanya manusia. Elemen - elemen tersebut adalah teknologi ( peralatan, metode kerja ) yang digunakan, kualitas dari input ( termasuk material), kualitas lingkungan fisik ( keselamatan, kesehatan kerja,lay out tempat kerja dan kebersihan ), iklim dan budaya organisasi ( termasuk supervisi dan kepemimpinan ) dan sistem kompensasi dan imbalan. Kegiatan dengan ruang lingkup seperti ini merupakan sebuah proyek besar dan melibatkan hampir semua orang, dan ditangani langsung oleh pimpinan puncak organisasi. Setelah pimpinan organisasi menetapkan tujuan dari program tersebut, misalnya meningkatkan produktifitas pabrik atau meningkatkan kinerja sebuah bank ke arah tertentu yang dapat diukur maka team 


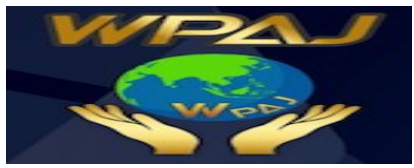

Volume 2 Issue 1, Juni 2020

http://ejournal.unsub.ac.id/index.php/publik

pelaksana akan meneliti kondisi dan status dari tiap-tiap elemen, dan menetapkan tindakan apa yang harus dilakukan.

\section{c. Tujuan dan Manfaat Manajement Kinerja}

ujuan yang biasanya dapat dicapai oleh sebuah organisasi atau perusahaan dengan menerapkan sistem manajemen kinerja seperti pendapat Ruky ( $2001: 39$ ) dapat dilihat dari uraian berikut.

1. Meningkatkan prestasi kerja karyawan baik secara individu maupun sebagai kelompok sampai setinggi-tingginya dengan memberikan kesempatan pada mereka untuk memenuhi kebutuhan aktualisasi dirinya dalam kerangka pencapaian tujuan perusahaan. Karyawan bersama atasan masing-masing dapat menerapkan sasaran kerja dan standar prestasi yang harus dicapai dan meneliti serta menilai hasil-hasil yang sebenarnya dicapai pada akhir kurun waktu yang ditetapkan.

2. Peningkatan yang terjadi pada prestasi karyawan secara perorangan pada gilirannya akan mendorong kinerja sumber daya manusia secara keseluruhan, yang direfleksikan dalam kenaikan produktifitas. Dengan kata lain peningkatan produktifitas sumber daya manusia secara keseluruhan diusahakan dicapai melalui peningkatan prestasi kerja karyawan secara perorangan (individu )

3. Merangsang minat dalam pengembangan pribadi dalam tujuan meningkatkan hasil karya dan prestasi pribadi serta potensi laten karyawan dengan cara memberikan umpan balik pada mereka tentang prestasi mereka.

4. Membantu perusahaan untuk dapat menyususn program pengembangan dan pelatihan karyawan yang lebih tepat guna. Usaha ini akan membantu perusahaan untuk mempunyai pasokan tenaga yang cakap dan terampil yang cukup untuk pengembangan perusahaan di masa depan.

5. Menyediakan alat/sarana untuk membandingkan prestasi kerja pegawai dengan tingkat gajinya atau imbalanya sebagai dari kebijakan dan sistem imbalan yang baik.

6. Memberikan kesempatan kepada pegawai untuk mengeluarkan perasaanya tentang pekerjaan atau hal-hal yang ada kaitanya. Dengan demikian jalur komunikasi dan dialog akan terbuka dan dengan demikian diharapkan bahwa proses penelitian prestasi kerja akan mengeratkan hubungan antara atasan dan bawahan.

\section{d. Standar Kinerja}

Menurut Sayle dan Strauss yang dikutip dan diterjemahkan oleh Sedarmayanti (2001:51), bahwa standar kinerja adalah: "ukuran dalam hal mengadakan perbandingan antara apa yang telah dilakukan dengan apa yang diharapkan, yang kaitannya dengan pekerjaan atau jabatan yang dipercayakan pada seseorang".

Dari pengertian di atas maka dapat disimpulakan bahwa standar kinerja pada dasamya adalah ukuran yang digunakan dalam membandingkan antara apa yang nantinya diharapkan terjadi atas suatu pekerjaan atau tugas yang diembankan kepada seseorang dalam suatu perusahaan atau organisasi tempat seseorang bekerja. Standar kinerja tidak selamanya berjalan sesuai dengan apa yang diharapkan. Terkadang 


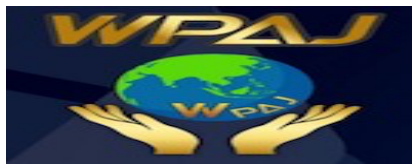

Volume 2 Issue 1, Juni 2020

http://ejournal.unsub.ac.id/index.php/publik

hasilnya positif atau dapat juga hasilnya negatif, karena itu diperlukan kebijakan dan pengendalian yang bersifat menyeluruh sehingga dapat mengakomodir berbagai kepentingan dengan dua arah yang jelas.

\section{e. Indikator Kinerja}

Indikator Kinerja atau performance Indikator kadang-kadang dipergunakan secara bergantian dengan ukuran kinerja (performance measures), tetapi banyak yang membedakannya pengukuran kinerja berkaitan dengan hasil yang dapat dikuantitatifkan dan mengusahakan data setelah kejadian.

Sementara itu, indikator kinerja dipakai untuk aktivitas yang hanya dapat ditetapkan secara lebih kualitatif atas dasar perilaku yang dapat diamati. Indikator kinerja juga menganjurkan sudut pandang prospektif (harapan ke depan) dari pada retrospektif (melihat ke belakang). Hal ini menunjukkan jalan pada aspek kinerja yang perlu diobservasi. Terdapat tujuh indikator kinerja. Dua di antaranya mempunyai peran sangat penting, yaitu tujuan dan motif Kinerja ditentukan oleh tujuan yang hendak dicapai dan untuk melakukannya diperlukan adanya motif Tanpa dorongan motif untuk mencapai tujuan, kinerja tidak akan berjalan. Dengan demikian, tujuan dan motif menjadi indikator utama dari kinerja.

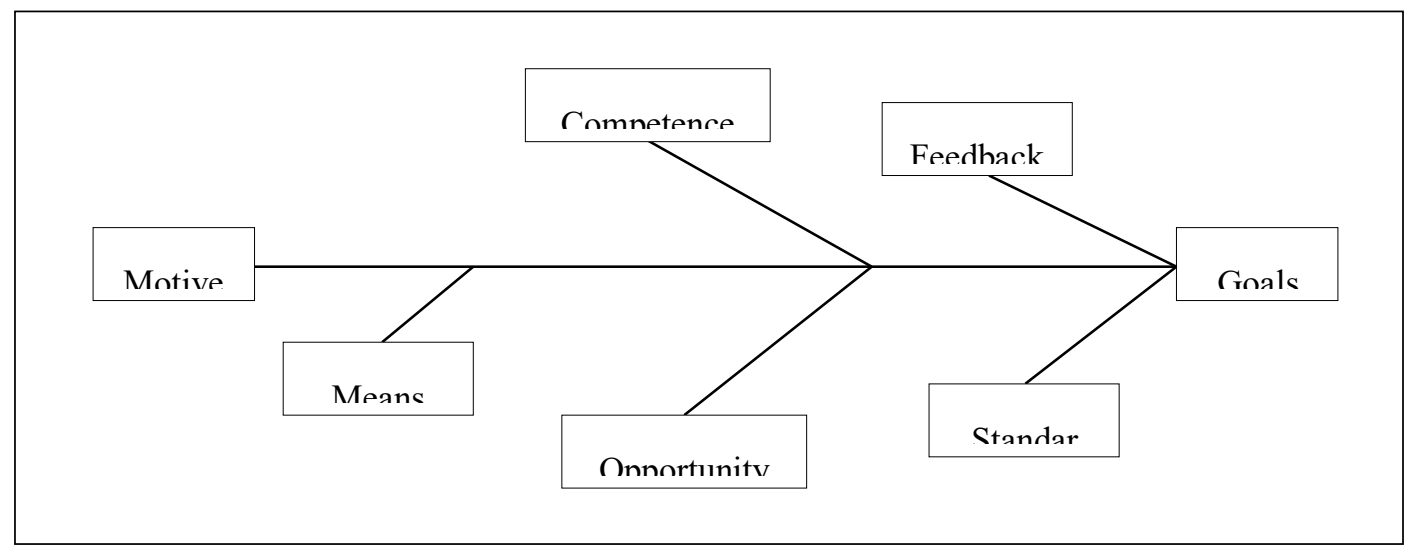

Gambar 1 : Indikator Kinerja

Sumber : Paur Hersey et. all, dalam Wibowo $(2010: 102)$

Namun kinerja memerlukan adanya dukungan sarana, kompetensi, peluang, standar,

1. Tujuan

ujuan merupakan keadaan yang berbeda yang secara aktif dicari oleh seorang individu atau organisasi untuk dicapai. Pengertian tersebut mengandung makna bahwa tujuan bukanlah merupakan persyaratan, juga bukan merupakan sebuah keinginan.Tujuan merupakan sesuatu keadaan yang lebih baik yang ingin dicapai 
di masa yang akan datang. Dengan demikian, tujuan menunjukkan arah ke mana kinerja harus dilakukan. Atas dasar arah tersebut, dilakukan kinerja untuk mencapai tujuan. Untuk mencapai tujuan, diperlukan kinerja individu, kelompok, dan organisasi.

inerja individu maupun organisasi berhasil apabila dapat mencapai tujuan yang diinginkan.

2. Standar

tandar mempunyai arti penting karena memberitahukan kapan suatu tujuan dapat diselesaikan. Standar merupakan suatu ukuran apakah tujuan yang diinginkan dapat dicapai. tanpa standar, tidak dapat diketahui kapan suatu tujuan capai.Standar menjawab pertanyaan tentang kapan kita tahu bahwa kita sukses atau gagal. Kinerja seseorang dikatakan berhasil apabila mampu mencapai standar yang ditentukan atau disepakati bersama antara atasan dan bawahan.

3. Umpan Balik

ntara tujuan, standar, dan umpan balik bersifat saling terkait. Umpan balik melaporkan kemajuan, baik kualitas maupun kuantitas, dalam mencapai tujuan yang didefinisikan oleh standar. Umpan balik terutama penting ketika kita mempertimbangkan "real goals" atau tujuan sebenamya. Tujuan yang dapat diterima oleh pekerja adalah tujuan yang bermakna dan berharga.Umpan balik merupakan masukan yang dipergunakan untuk mengukur kemajuan kinerja, standar kinerja, dan pencapaian tujuan. Dengan umpan balik dilakukan evaluasi terhadap kinerja dan sebagai hasilnya dapat dilakukan perbaikan kinerja.

4. Alat atau Sarana

lat atau sarana merupakan sumber daya yang dapat dipergunakan untuk membantu menyelesaikan tujuan dengan sukses. Alat atau sarana merupakan faktor penunjang untuk pencapaian tujuan. Tanpa alat atau sarana, tugas pekerjaan spesifik tidak dapat dilakukan dan tujuan tidak dapat diselesaikan sebagaimana seharusnya. Tanpa alat tidak mungkin dapat melakukan pekerjaan.

5. Kompetensi

ompetensi merupakan persyaratan utama dalam kinerja. Kompetensi merupakan kemampuan yang dimiliki oleh seseorang untuk menjalankan pekerjaan yang diberikan kepadanya dengan baik. Orang harus melakukan lebih dari sekadar belajar tentang sesuatu, orang harus dapat melakukan pekerjaannya dengan baik. Kompetensi memungkinkan seseorang mewujudkan tugas yang berkaitan dengan pekerjaan yang diperlukan untuk mencapai tujuan.

6. Motif

otif merupakan alasan atau pendorong bagi seseorang untuk melakukan sesuatu. Manajer memfasilitasi motivasi kepada karyawan dengan insentif berupa uang, memberikan pengakuan, menetapkan tujuan menantang, menetapkan standar terjangkau, meminta umpan balik, memberikan kebebasan melakukan pekerjaan 


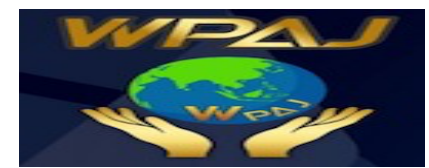

Volume 2 Issue 1, Juni 2020

http://ejournal.unsub.ac.id/index.php/publik

termasuk waktu melakukan pekerjaan, menyediakan sumber daya yang diperlukan dan menghapuskan tindakan yang mengakibatkan disintensif.

7. Peluang

ekerja perlu mendapatkan kesempatan untuk menunjukkan prestasi kerjanya. Terdapat dua. faktor yang menyumbangkan pada adanya kekurangan kesempatan untuk berprestasi, yaitu ketersediaan waktu dan kemampuan untuk memenuhi syarat. Tugas mendapatkan prioritas lebih tinggi, mendapat perhatian lebih banyak, dan mengambil waktu yang ter- sedia. jika pekerja dihindari karena supervisor tidak percaya terhadap kualitas atau kepuasan konsumen, mereka secara efektif akan dihambat dari kemampuan memenuhi syarat untuk berprestasi.

\section{Hasil dan Pembahasan}

\section{Kinerja UPTD Rumah Potong Hewan (RPH) Subang pada Dinas Peternakan dan}

Perusahaan daerah rumah pemotongan hewan merupakan alat kelengkapan otonomi daerah yang diharapkan secara berkesinambungan mampu mengoptimalkan pelayanan kepada masyarakat luas dalam penyediaan daging higenis layak dikonsumsi meskipun tetap bertujuan untuk mencari laba \{profit oriented). Rumah pemotongan hewan memberikan pelayanan di bidang pemotongan hewan khususnya kepada para jagal, juga kepada msyarakat umum (potongan hajad) dan sebagai tempat belajar bagi siswa/mahasiswa yang ingin mempelajari cara pemotongan maupun kegiatan yang ada di RPH.

Unit Pelaksana Teknis Dinas (UPTD) merupakan unsur pelaksana teknis operasional dinas di bidang Rumah Potong Hewan (RPH) dan Rumah Potong Unggas (RPU) yang dibentuk berdasarkan Peraturan Bupati Subang, Nomor : 14G.13 Tahun 2008, tentang Tugas Pokok Dan Fungsi Unit Pelaksana Teknis Dinas Rumah Potong Hewan (RPH) Dan Rumah Potong Unggas (RPU) Dinas Petemakan Kabupaten Subang. Unit Pelaksana Teknis Dinas (UPTD) dipimpin oleh seorang Kepala UPTD yang berada dibawah dan bertanggung jawab kepada Kepala Dinas.

Kemampuan kerja pegawai merupakan aspek penting dalam organisasi. Pegawai yang memiliki kemampuan kerja dalam melaksanakan tugas akan senantiasa bekcrja percaya diri dan siap untuk menyelesaikan setiap permasalahan yang terjadi. Komunikasi dalam melaksanakan tugas dan tanggung jawabnya akan mempengaruhi kinerja yang diberikan dengan ditandai oleh tingkat produktivitas, kestabilan yang dimiliki dalam melaksanakan tugas, kedisiplinan yang kuat, loyalitas yang tinggi, tanggung jawab serta efektivitas dan efisiensi dalam melaksanakan tugas. Kedua aspek tersebut jika bersatu secara utuh dalam kondisi baik akan menjadikan pegawai berperilaku sesuai dengan tuntutan organisasi yang dikehendaki. Oleh karena itu apapun bentuk organisasinya aspek kemampuan kerja dan komunikasi perlu mendapatkan perhatian yang serius dari pimpinan organisasi tersebut, 


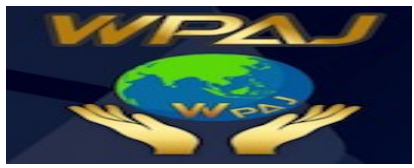

Volume 2 Issue 1, Juni 2020

http://ejournal.unsub.ac.id/index.php/publik

termasuk di UPTD Rumah Potong Hewan Subang Dinas Peternakan dan Kesehatan Hewan Kabupaten Subang.

Kinerja bisa juga dikatakan sebagai sebuah hasil (output) dari suatu proses tertentu yang dilakukan oleh seluruh komponen organisasi terhadap sumber-sumber tertentu yang digunakan (input). Selanjutnya, kinerja juga merupakan hasil dari serangkaian proses kegiatan yang dilakukan untuk mencapai tujuan tertentu organisasi. Bagi suatu organisasi, kinerja merupakan hasil dari kegiatan kerjasama diantara anggota atau komponen organisasi dalam rangka mewujudkan tujuan organisasi. Untuk mengetahui Kinerja UPTD Rumah Potong Hewan (RPH) Subang pada Dinas Peternakan dan Kesehatan Hewan Kabupaten Subang sesuai dengan teori kinerja menurut pendapat Hersey et. all dalam Wibowo (2010 : 102) yang terdiri dari : 1) Tujuan, 2) Standar, 3) Umpan Balik, 4) Alat atau Sarana, 5) Kompetensi, 6) Motif, 7) Peluang. Adapun hasil penelitian dan pembahasan mengenai Kinerja UPTD Rumah Potong Hewan (RPH) yang di deskripsikan sebagai berikut:

\section{a. Tujuan}

Tujuan merupakan keadaan yang berbeda yang secara aktif dicari oleh seorang individu atau organisasi untuk dicapai. Pengertian tersebut mengandung makna bahwa tujuan bukanlah merupakan persyaratan, juga bukan merupakan sebuah keinginan.Tujuan merupakan sesuatu keadaan yang lebih baik yang ingin dicapai di masa yang akan datang. Dengan demikian, tujuan menunjukkan arah ke mana kinerja harus dilakukan. Atas dasar arah tersebut, dilakukan kinerja untuk mencapai tujuan. Untuk mencapai tujuan, diperlukan kinerja individu, kelompok, dan organisasi. Kinerja individu maupun organisasi berhasil apabila dapat mencapai tujuan yang diinginkan.

UPTD Rumah Potong Hewan (RPH) Subang Dinas Petemakan Kabupaten Subang menetapkan tujuan dan sasaran yang ingin dicapai yaitu pelayanan yang baik kepada para pengguna Rumah Potong Hewan sesuai dengan SOP dan peraturan menteri pertanian tentang kesehatan masyarakat veteriner (kesmavet). Hasil wawancara penulis dengan Kepala Unit Pelaksana Teknis Dinas Rumah Potong Hewan Subang Dinas Petemakan Kabupaten Subang tentang Tujuan yang ingin dicapai oleh UPTD Rumah Potong Hewan (RPH) adalah sebagai berikut:

Tujuan yang ingin dicapai dengan cara memberikan pelayanan yang terbaik bagi masyarakat pengguna jasa RPH dengan memperbaiki prosedur yang ada,serta memperbaiki pelayanan pemotongan dan unit pengolahan daging. Berdasarkan hasil wawancara dengan Kepala UPTD, bahwa UPTD mempunyai tujuan dapat mendorong pemanfaatan potensi sumberdaya petemakan secara optimal dalam rangka meningkatkan ketahanan dan kemanan pangan dan dapat menggiring terciptanya lingkungan usaha yang kondusif bagi peningkatan daya saing komunitas petemakan di pasar domestic dan global.

Rumah Pemotongan Hewan (RPH) Subang merupakan Unit Pelaksana Teknis Dinas (UPTD) yang berada dibawah naungan Dinas Petemakan dan Kesehatan Hewan Kabupaten Subang. RPH sebagai unit pelayanan publik memiliki fungsi 


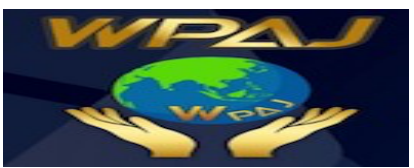

teknis, ekonomis dan sosial dimana dalam pelaksanaanya mengacu pada Visi dan Misi Dinas Petemakan dan Kesehatan Hewan Kabupaten Subang. Dari aspek sosial $\mathrm{RPH}$ memberikan ketentraman batin kepada masyarakat dari kemungkinan penularan penyakit zoonosis dan penyakit atau keracunan makanan (Food Born Disease dan Food Born Intoxication) melalui penyediaan daging yang Aman, Sehat, Utuh dan Halal (ASUH).

Berdasarkan hasil observasi dan hasil wawancara bahwa tujuan yang ingin dicapai oleh UPTD Rumah Potong Hewan Dinas Petemakan dan Kesehatan Hewan Kabupaten Subang adalah memberikan pelayanan yang terbaik bagi masyarakat pengguna jasa RPH dengan memperbaiki prosedur yang ada, serta memperbaiki pelayanan pemotongan dan unit pengolahan daging, pada kenyataannya pelayanan yang diberikan oleh Rumah Potong Hewan masih beium sesuai dengan sasaran yang ingin dicapai, itu terlihat dari hasil observasi terlihat bahwa Rumah Potong Hewan beium memiliki Dokter Hewan tetap sehingga tidak dapat mengawasi atau memeriksa hewan yang akan dipotong setiap saat, peraiatan yang digunakan sudah tidak sesuai dengan persyaratan Rumah Potong Hewan, para pemotong hewan bukan pegawai tetap, melainkan pegawai harian lepas yang sistem gajinya berdasarkan jumlah hewan yang dipotong.

\section{b. Standar}

Standar mempunyai arti penting karena memberitahukan kapan suatu tujuan dapat diselesaikan. Standar merupakan suatu ukuran apakah tujuan yang diinginkan dapat dicapai. tanpa standar, tidak dapat diketahui kapan suatu tujuan capai. Standar menjawab pertanyaan tentang kapan kita tahu bahwa kita sukses atau gagal. Kinerja seseorang dikatakan berhasil apabila mampu mencapai standar yang ditentukan atau disepakati bersama antara atasan dan bawahan.

Rumah Potong Hewan yang secara resmi dibawah pengawasan Departemen Pertanian, pada dasarnya mempunyai persyaratan, sesuai dengan Surat Keputusan Menteri Pertanian Nomor 555/Kpts/TN.240/1986, tentang syarat-syarat rumah pemotongan hewan. Pasa! 2 dari SK Mentan tersebut menyatakan bahwa Rumah Potong Hew'an merupakan unit/ sarana pelayanan masyarakat dalam penyediaan daging sehat. Lebih lanjut pada bab II dari SK Mentan tersebut mengungkapkan mengenai syarat-syarat $\mathrm{RPH}$ yang dijelaskan lebih rinci pada pasal 3 ayat (a) menyatakan bahwa RPH berlokasi di daerah yang tidak menimbulkan gangguan atau peneemaran lingkungan misalnya dibagian pinggir kota yang tidak padat penduduknya.

Berikut hasil wawancara penulis dengan Kepala Unit Pelaksana Teknis Dinas Rumah Potong Hewan mengenai standar pelayanan yang telah ditetapkan oleh UPTD Rumah Potong Hewan (RPH) Dinas Peternakan dan Kesehatan Hewan Kabupaten Subang yaitu : Standar pelayanan yang diterapkan RPPI sudah sesuai dengan permentan tentang kesmavet dan HAUS (Halal, Aman, Utuh dan Sehat), tetapi pelayanan belum maksimal karena belum memenuhi standar nasional yang telah ditetapkan oleh pemerintah. 
Hasil wawancara tersebut di atas berbeda dengan hasil wawancara dengan Perwakilan masyarakat pengguna jasa UPTD Rumah Potong Hewan Subang mengenai pelayanan yang diberikan oleh RPH sudah sesuai dengan aturan yang telah ditetapkan oleh UPTD RPH Subang Dinas Peternakan dan Kesehatan Hewan Kabupaten Subang sebagai berikut : Pelayanan di RPH belum memenuhi standar nasional karena kurang kepeduliannya pegawai RPH untuk memberikan kenyamanan terhadap pelayanan itu seperti hewan asal dipotong saja tanpa adanya pengamanan yang sesuai standar yang ada, penimbangan daging hewan yang sudah di potong, alatnya kadang rusak memakai alat yang lama, daging yang sudah dipotong asal dimasukin ke karung saja tanpa adanya pemeriksaan terlebih dahulu oleh petugas $\mathrm{RPH}$, mereka petugas $\mathrm{RPH}$ hanya menarik retribusi saja tanpa adanya pelayanan yang baik terhadap masyarakat pemotong hewan dan penjual daging.

Berdasarkan hasil penelitian dapat dikemukakan bahwa Rumah Pemotongan Subang diperlukan sarana untuk pelayanan kepada masyarakat dalam penyediaan daging sehat yang sesuai dengan perkembangan yang terjadi. Untuk mengatasi permasalahan tersebut diperlukan adanya Relokasi RPH di Kabupaten Subang dan Perencanaan dan Perancangan tentang Rumah Pemotongan Hewan Subang yang lebih menekankan pada fungsi proses produksi sehingga tercipta keefektifan di lokasi yang baru, dengan ketemuan tentang persyaratan Rumah Pemotongan hewan yang sesuai dengan kcputusan pemerintah yang berlaku. Jadi faktor yang penghambat untuk menetapkan standar kualitas pelayanan yang diberikan kepada pengguna jasa rumah potong hewan adalah faktor sarana prasaran yang sudah tidak mendukung dan sudah tidak sesuai dengan standar SNI tentang rumah potong hewan No. 016159-1999 dan Peraturan Menteri Pertanian Nomor 13/Permentan/OT. 140/1/2010 tentang Persyaratan Rumah Potong Hewan dan Unit Penanganan Daging dikarenakan faktor anggaran yang belum terrealisasi untuk merelokasi rumah potong hewan.

\section{c. Umpan Balik}

Antara tujuan, standar, dan maupan balik bersifat saling terkait. Umpan balik melaporkan kemajuan, baik kualitas maupun kuantitas. dalam mencapai tujuan yang didefinisikan oleh standar. Umpan balik terutama penting ketika kita mempertimbangkan "real goals" atau tujuan sebenarnya. Tujuan yang dapat diterima oleh pekerja adalah tujuan yang bermakna dan berharga. Umpan balik merupakan masukan yang dipergunatan untuk mengukur kemajuan kinerja, standar kinerja, dan pencapaian tujuan, Dengan umpan balik dilakukan evaluasi terhadap kinerja dan sebagai hasilnya dapat dilakukan perbaikan kinerja.

Berikut wawancara penulis dengan Kepala Unit Pelaksana Teknis Dinas Rumah Potong Hewan mengenai hasil retribusi yang dihasilkan oleh UPTD Rumah Potong Hewan (RPH) Dinas Petemakan Kabupaten Subang sudah mencapai target yang ditetapkan oleh pemerintah sebagai berikut: Untuk tahun anggaran 2018 UPTD RPH tidak mencapai target hanya 56\%, Retribusi yang telah di tetapkan RPH tidak memenuhi target yang telah ditetapkan PAD Kabupaten Subang, dikarenakan kurang optimalnya pemanfaatan $\mathrm{RPH}$ itu sendiri jadi daya minat masyarakat pemotong 


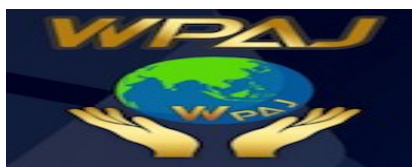

hewan dan pedagang daging kurang tertarik dan lebih memotong diluar/dirumah potong sendiri dari pada di RPH yang jelas-jelas terjamin mutu kehalalan dagingnya, serta kelayakan daging yang baik untuk dikonsumsi maupun tidak.

Retribusi Rumah Potong Hewan merupakan nama dari pungutan retribusi atas pelayanan penyediaan fasilitas di Rumah Potong Hewan. Objek Retribusi Rumah Potong hewan sebagaimana dimaksud di atas adalah pelayanan penyediaan fasilitas rumah pemotongan hewan temak yang disediakan, dimiliki dan/atau dikelola oleh Pemerintah Daerah, Dikecualikan dari Objek Retribusi sebagaimana dimaksud adalah pelayanan penyediaan fasilttas Rumah Pemotongan Hewan Ternak yang disediakan, dimiliki dan/atau dikelola oleh BUMN, BUMD dan piliak swasta, Tingkat penggunaan jasa retribusi Rumah Potong Hewan diukur berdasarkan jenis hewan dan volume/sampel. Struktur besarnya tarif retribusi Rumah Potong Hewan ditetapkan sebagai berikut:

1. Retribusi Kandang Penampungan:

a. Temak besar sebesar Rp 5000,- per ekor;

b. Temak kecil sebesar Rp 1,000,- per ekor;

c. Unggas sebesar Rp 100,- per ekor.

2. Retribust pemotongan:

a. Temak besar sebesar Rp 20,000,- per ekor;

b. Temak kecil sebesar Rp 5000,- per ekor;

c. Unggas sebesar Rp 100,- per ekor

Retribusi untuk jenis hewan lainnya disesuaikan dengan jenis hewan sebagaimana objek retribusi Rumah Potong hewan, Subjek Retribusi Rumah Potong Hewan adalah orang pribadi dan/atau badan yang memanfaatkan/menggunakan fasilitas Rumah Potong Hewan yang disediakan, dimiliki dan/atau dikelola oleh Pemerintah Daerah.

Berdasarkan hasil observasi dan wawancara di atas bahwa umpan balik yang diberikan oleh UPTD Rumah Potong Hewan Subang Dinas Peternakan Kabupaten Subang masih jauh dari harapan yang diinginkan oleh para pengguna jasa Rumah Potong Hewan. UPTD Rumah Potong Hewan Subang Dinas Peternakan Kabupaten Subang belum menyiapkan kotak. saran sebagai sarana komunikasi antara Rumah Potong Hewan dengan pengguna jasa 3 sehingga umpan balik tidak terjadi, hanya berjalan satu kali saja.

\section{d. Alat atau Sarana}

Alat atau sarana merupakan sumber daya yang dapat dipergunakan untuk membantu menyelesaikan tujuan dengan sukses. Alat atau sarana merupakan faktor penunjang untuk pencapaian tujuan. Tanpa alat atau sarana, tugas pekerjaan spesifik tidak dapat dilakukan dan tujuan tidak dapat diselesaikan sebagaimana seharusnya, Tanpa alat tidak mungkin dapat melakukan pekerjaan.

Berdasarkan hasil wawancara dan observasi bahwa Rumah Potong Hewan Subang Dinas Peternakan Kabupaten Subang belum memiliki sarana prasarana yang memenuhi standar sesuai dengan syarat-syarat Rumah Potong hewan (RPH) sudah diatur juga di dalam SK Menteri Pertanian Nomor 555/Kpls/TN.240/9/1986. 
Persyaratan ini dibagi menjadi prasyaratan untuk $\mathrm{RPH}$ yang digunakan untuk memotong hewan guna memenuhi kebutuhan lokal di Kabupaten/Kotamadya Daerah Tingkat II, memenuhi kebutuhan daging antar Kabupaten/Kotamadya Daerah Tingkat II dalam satu Propinsi Daerah Tingkat I, memenuhi kebutuhan daging antar Propinsi Daerah Tingkal I dan memenuhi kebutuhan eksport (Manual Kesmavet, 1993). Berdasarkan obsevasi dan penelitian di lapangan bahwa Rumah Potong Hewan Subang Dinas Petemakan Kabupaten Subang masih belum memiliki peralatan yang standar yang sesuai dengan ketentuan dalam SK. Menteri Pertanian Nomor 555/Kpts/TN.240/9/1986. Persyaratan ini dibagi menjadi prasyarat untuk $\mathrm{RPH}$ yang digunakan untuk memotong hewan guna memenuhi kebutuhan lokal di Kabupaten/Kotamadya Daerah Tingkat II, sehingga pemerintah Kabupaten Subang melalui Dinas Petemakan harus segera membenahi Rumah Potong hewan tersebut guna meningkatkan kinerja Rumah Potong Hewan tersebut.

Idealnya UPTD Rumah Potong Hewan Subang Dinas Petemakan Kabupaten Subang memiliki Fasilitas Rumah Potong hewan modem mulai diberikan seperti restrain box, air blast freezer, freezer, dan cold storage sehingga produk daging yang dlhasilkan selain daging segar juga menyediakan daging beku, selain itu Rumah Potong Hewan Ini dilengkapi dengan sarana penggolahan limbah yang memadai. UPTD Rnmah Potong Hewan Subang Dinas Petemakan Kabupaten Subang belum bisa melengkapi Rumah Potong Hewan dengan perlengkapan yang sesuai dengan Standar yang ditetapkan oleh Menteri Pcrtanian tersebut dikarenakan belum adanya pengajuan anggaran dari Dinas Petemakan Kabupaten Subang untuk merenopasi Rumah Potong hewan, sehingga UPTD Rumah Potong Hewan Subang Dinas Petemakan Kabupaten Subang masih mempergunakan peralatan yang lama yang belum sesuai dengan standar yang telah ditetapkan oleh pemerintah.

\section{e. Kompetensi}

Kompetensi merupakan persyaratan utama dalam kinerja. Kompetensi merupakan kemampuan yang dimiliki oleh seseorang untuk menjalankan pekerjaan yang diberikan kepadanya dengan baik, Orang harus melakukan lebih dari sekadar belajar tentang sesuatu, orang harus dapat melakukan pekerjaannya dengan baik.

Idealnya Rumah Potong Hewan yang dikelola oleh Pemerintah Daerah harus sudah ebih baik terutama dalam Sumber Daya Manusia yang mengelola Rumah Potong Hewan tersebut diantaranya harus ada Dokter yang bertugas tetap untuk memeriksa kesehatan hewan yang akan di potong, para pegawainya sudah memiliki sertifikat pelatihan untuk pengelolaan limbah, pengelolaan daging dan pengelolaan pemeriksaan lab.

Acuan tentang Rumah Pemotongan Hewan (RPH) dan tatacara pemotongan yang baik dan halal di Indonesia sampai saat ini adaiah Statidar Nasional Indonesia (SNl) 01-6159-1999 tentang Rumah Pemotongan Hewan berisi beberapa persyaratan yang berkaitan dengan RPH termasuk persyaratan lokasi, sarana, bangunan dan tata letak sehingga keberadaan RPH tidak menimbulkan ganguan berupa polusi udara dan limbah buangan yang dihasilkan tidak mengganggu masyarakat. 
Berikut adalah hasil wawancara penulis dengan Kepala Unit Pelaksana Teknis Dinas Rumah Potong Hewan mengenai kompetensi pegawai pada UPTD Rumah Potong Hewan (RPH) Dinas Peternakan dan Kesehatan Hewan Kabupaten Subang sebagai berikut; Kompetensi pegawai UPTD Rumah Potong Hewan, khususnya yang dikelola pemerintah belum memenuhi standar yang diperuntukan bagi Rumah Potong Hewan, diantaranya kurangnya Lembaga keurmister dan dokter hewan di Rumah Potong Hewan. Dinas Peternakan hanya memiliki Dokter hewan sebanyak 4 orang yang menangani seluruh wilayah Kabupaten Subang, sehingga Dokter hewan bertugas ke setiap Rumah Potong Hewan milik pemerintah secara bergiliran, jadi tidak ada dokter yang bertugas tetap di Rumah Potong Hewan.

Dari hasil wawancara terlihat bahwa kompetensi pegawai di UPTD Rumah Potong Hewan Subang Dinas Peternakan Kabupaten Subang masih belum sesuai dengan kompetensi yang seharusnya dimiliki oleh pegawai Rumah Potong Hewan, karena pegawai tersebut bukan dari latar belakang pendidikan Dokter Hewan, tetapi dari tenaga teknis yang diberi pelatihan, dan tidak adanya Dokter Hewan yang bertugas tetap di Rumah Potong Hewan ini, serta petugas yang memotong hewan temak merupakan pegawai tidak tetap yang dibayar sesuai dengan jumlah hewan yang dipotong.Sebetulnya masalah Sumber Daya Manusia dapat diselesaikan dengan cara membuka lowongan yang seluas-luasnya kepada masyarakat yang memiliki kompetensi yang dibutuhkan untuk melamar, tetapi itu tidak bisa dilakukan dikarenakan rekrutmen pegawai Rumah Potong Hewan Dinas Petemakan Kabupaten Subang barus berdasarkan penerimaan pegawai dari Pemerintah Daerah, dan kuotanya tidak bisa banyak karena disesuaikan dengan jumlah anggaran yang tersedia untuk gaji pegawai baru.

Mengingat beberapa permasalahan tersebut di atas maka setiap kegiatan yang bergerak dan berhubungan dengan penanganan daging harus dilaksanakan dengan memenuhi persyaratan kesehatan masyarakat veteriner. Sehingga masyarakat konsumen daging akan dapat memperoleh manfaat dan nilai kelebihan akan gizinya serta sekaligus dapat terhindar dari penularan penyakit zoonosis. Diharapkan dengan adanya Rumah Potong Hewan Terpadu dapat memberikan pelayanan yang berkualitas dengan berorientasi kepada kebutuhan dan kepuasan masyarakat.

\section{f. Motif}

Motif merupakan alasan atau pendorong bagi seseorang untuk melakukan sesuatu. Manajer memfasilitasi motivasi kepada karyawan dengan insentif berupa uang, memberikan pengakuan, menetapkan tujuan menantang, menetapkan standar terjangkau, meminta umpan balik, memberikan kebebasan melakukan pekerjaan. termasuk waktu melakukan pekerjaan, menyediakan sumber daya yang diperlukan dan menghapuskan tindakan yang mengakibatkan disintensif.

Berikut ini adalah hasil wawancara penuh dengan Kepala Unit Pelaksana Teknis Dinas Rumah Potong Hewan mengenai motivasi kerja pegawai pada UPTD Rumah Potong Hewan (RPH) Dinas Petemakan Kabupaten Subang sebagai berikut: Kurangnya motivasi para pegawai RPH disebabkan karena tidak adanya kepedulian dari pihak pimpinan UPTD alau KADIS Petemakan untuk memberikan reward 


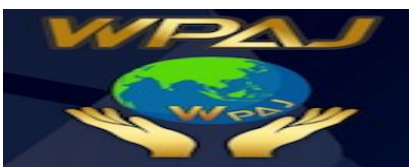

Volume 2 Issue 1, Juni 2020

http://ejournal.unsub.ac.id/index.php/publik

kepada mereka apabila bisa menarik masyarakat petemak yang akan memotong hewan atau pedagang daging untuk datang ke RPH sehingga mereka para pegawainya akhirnya tidak ada tantangan untuk meningkatkan kinerjanya reward itu bisa berupa bonus akhir bulan atau pertriwulan apabila melebihi target yang sudah ditentukan atau memberikan peningkatan golongan apabila kinerjanya baik bagi yang sudah PNS.

Begitu pula dengan UPTD Rumah Potong Hewan (RPH) Dinas Peternakan dan Kesehatan Hewan Kabupaten Subang untuk dapat meningatkan motivasi kerja anggotanya berupaya memberikan tanggung jawab, karena tanggungjawab merupakan kesanggupan seseorang untuk menyelesaikan pekerjaan yang diserahkan kepadanya dengan sebaik- baiknya tepat pada waktunya serta berani memikul resiko atas keputusan yang diambilnya atau tindakan yang dilakukannya. Pemberian penghargaan kepada anggota, karena penghargaan terlupakan suatu kebutuhan yang berdimensi dua, sebagian dimensi kebutuhan penghargaan ini adalah kebutuhan harga diri, kemampuan harga diri kemampuan seseorang yang berkeja pada orang lain. Dimensi yang lain adalah kebutuhan untuk menerima pengakuan dan penghargaan dari orang orang yang menjadi temannya, Dan membina hubungan antar anggota setingkat yang baik akan mendukung pekerjaan mereka. Hubungan antara anggota setingkat akan menimbulkan saling kerjasama. Saling membantu, sedangkan hubungan antara atasan dengan anggota di bawah akan menjadikan komando yang serasi. Artinya anggota pada bagian bawah tidak hanya diperintah akan tetapi akan merasa senang melakukan semua pekerjaan yang diberikan dari atasannya.

\section{g. Peluang}

Pekerja perlu mendapatkan kesempatan untuk menunjukkan prestasi kerjanya. Terdapat dua faklor yang menyumbangkan pada adanya kekurangan kesempatan untuk berprestasi, yaitu ketersediaan waktu dan kemampuan untuk memenuhi syarat. Tugas mendapatkan prioritas lebih tinggi, mendapat perhatian lebih banyak, dan mengambil waktu yang tersedia, jika pekerja dihindari karena tidak percaya terhadap kualitas atau kepuasan konsumen, mereka secara efektif akan di hambat dan kemampuan memenuhi syarat untuk berprestasi.

Rumah Pemotongan Hewan (RPH) Kabupaten Subang, merupakan Unit pelaksana Teknis Dinas (UPTD) yang berada dibawah naungan Dinas Petermakan Kabupaten Subang. RPH sebagai unit pelayanan publik memiliki fungsi teknis, ekonomis dan sosial dimana dalam pelaksanaannya mengacu pada Visi dan Misi Dinas Petemakan Kabupaten Subang. Berikut ini adalah hasil wawancara penulis dengan Kepala Unit Pelaksana Teknis Dinas Rumah Potong Hewan mengenai peluang usaha yang dimiliki oleh UPTD Rumah Potong Hewan (RPH) Dinas Peternakan dan Kesehatan Hewan Kabupaten Subang karena ada pesaing yaitu RPH Swasta : Bila dibandingkan dengan RPH Swasta dalam peluang usaha selama ini RPH yang dikelola pemerintah kalah dalam bersaing itu dikarenakan RPH Swasta sudah lebih baik terutama dalam sarana dan prasarana dimana RPH Swasta sudah memperoleh serlifikat Nomor Kontrol Veteriner (NKV), sedangkan RPH pemerintah 


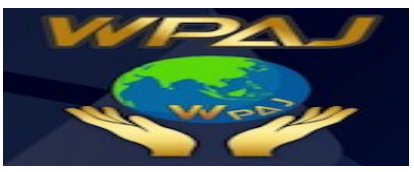

Volume 2 Issue 1, Juni 2020

http://ejournal.unsub.ac.id/index.php/publik

belum, Peluang yang dimiliki oleh UPTD RPH akan terancam punah apabila tidak meningkatkan kualitas dan kuantitas RPH itu sendiri, sedangkan RPH dari pihak swasta memiliki kualitas yang standar intemasional.

Dari data Dinas Peternakan dan Kesehatan Hewan Kabupaten Subang bahwa di Kabupaten Subang setiap bulan rata-rata kebutuhan konsutnsi daging sapi oleh masyarakat mencapai 132,7 ton atau setara dengan 456 ekor sapi. Dari kebutuhan konsumsi daging sapi itu, banya 27 persen yang bisa dipenuhi peternak lokal. Sedangkan 73 persen lagi mendatangkan temak dari luar daerah, mayoritas dari Provinsi Jawa Timur dan Jawa Tengah. Kebutuhan daging terebut tidak dapat terpenuhi oleh Rumah Potong Hewan hal tersebut karena adanya penurunan jumlah pemotongan setiap malamnya dimana biasanya semalam dapat memotong 10 sampai dengan 15 ekor, tetapi sekarang hanya 5 sampai dengan 8 ekor. Hal tersebut karena adanya Rumah Potong Hewan Swasta pada tahun sebelumnya tidak menjual daging ke Pasar Tradisional, mereka hanya menjual daging ke pasar swalayan dan supermarket, tapi semenjak terbatasnya sapi impor dan mahalnya harga sapi, maha Rumah Potong Hewan Swasta menjual dagingnya ke pasar tradisional yang harganya lebih murah dari Rumah Potong Hewan milik pemerintah.

Berdasarkan hasil wawancara yang penulis lakukan kepada beberapa informan maka kinerja Unit Pelayanan Teknis Dinas Rumah Potong Hewan (RPH) Pada Dinas Peternakan dan Kesehatan Hewan Kabupaten Subang belum optimal apabila merujuk kepada teori yang dikemukakan oleh Hersey et. all dalam Wibowo $(2010: 102)$.

\section{Faktor-faktor yang Menghambat Pencapaian Kinerja UPTD Rumah Potong Hewan}

1. Pelayanan yang diberikan oleh Rumah Potong Ilewan masih belum sesuai dengan sasaran yang ingin dicapai, karena Rumah Potong Hewan belum memiliki Dokter Hewan tetap sehingga tidak dapat mengawasi atau memeriksa hewan yang akan dipotong setiap saat, peralatan yang digunakan sudah tidak sesuai dengan pcrsyuratan Rumah Potong Hewan, dan para pemotong hewan bukan pegawai tetap melainkan pegawai harian lepas yang sistem gajinya berdasarkan jumlah hewan yang di potong.

2. Faktor yang menghambat untuk menetapkan standar kualitas pelayanan yang diberikan kepada pengguna jasa rumah potong hewan adalah faktor sarana prasaran yang sudah tidak mendukung dan sudah tidak sesuai dengan standar SNI tentang rumah potong hewan No. 01-6159-1999 dan Peraturan Menteri Pertanian Nomor 13/Permentan/OT. 140/1/2010 tentang Persyaralan Rumah Potong Hewan dan Unit Penanganan Daging dlkarenakan faktor anggaran yang belum terealisasi untuk merelokasi rumah potong hewan.

3. Kompetensi pegawai masih sangat kurang, para petugas pemotong temak merupakan karyawan harian lepas sehingga mereka tidak ada keterikatan dengan Rumah Potong Hewan, dan untuk tenaga Dokter Hewan juga tidak ada yang bertugas secara tetap tetapi dokter tersebut bertugas bergilir ke setiap Rumah Potong Hewan yang dikelola oleh Pemerintah melalui Dinas Petemakan 


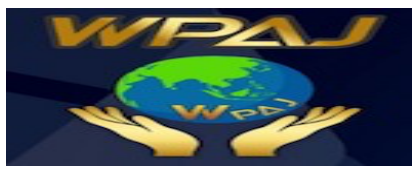

Volume 2 Issue 1, Juni 2020

http://ejournal.unsub.ac.id/index.php/publik

Kabupaten Subang.

4. Motivasi pegawai dalam pelaksanaan pelayanan masih kurang, karena mereka kurang mendapat dukungan dari pemerintah daerah, karena para pegawai kebanyakan statusnya masih sukarelawan, dan pegawai harian lepas.

\section{Kesimpulan}

Berdasarkan hasil penelitian yang penulis lakukan mengenai Kinerja UPTD Rumah Potong Hewan (RPH) Subang pada Dinas Petemakan dan Kesehatan Hewan Kabupaten Subang, maka penulis merumuskan kesimpulan sebagai berikut:

1. Kinerja UPTD Rumah Potong Hewan (RPH) Subang pada Dinas Petemakan Kabupaten Subang

a. Tujuan

Tujuan yang ingin dicapai oleh UPTD Rumah Potong Hewan Dinas Petemakan dan Kesehatan Hewan Kabupaten Subang adalah memberikan pelayanan yang terbaik bagi masyaiakat pengguna jasa RPH dengan memperbaiki prosedur yang ada, serta memperbaiki pelayanan pemotongan dan unit pengolahan daging.

b. Standar

Rumah Pemotongan Subang diperlukan sarana untuk pelayanan kepada masyarakat dalam penyediaan daging sehat yang sesuai dengan perkembangan yang terjadi. Untuk mengatasi permasalahan tersebut diperlukan adanya Relokasi RPH di Kabupaten Subang dan Perencanaan dan Perancangan tentang Rumah Pemotongan Hewan Subang yang lebih menekankan pada fungsi proses produksi sehingga tercipta keefektifan di lokasi yang baru dengan ketentuan tentang persyaratan Rumah Pemotongan Hewan yang sesuai dengan keputusan pemerintah yang berlaku.

c. Umpan Balik

Umpan balik terhadap pelayanan kepada pengguna jasa Rumah Potong Hewan, masih kurang memuaskan pihak pengguna jasa. Kualitas pelayanan yang diberikan oleh pegawai Rumah Potong Hewan masih jauh dari harapan, mereka memotong hewan ternaknya di UPTD Rumah Potong Hewan Subang Dinas Petemakan dan Kesehatan Hewan Kabupaten Subang karena tempatnya dekat dengan lingkungan pengguna jasa dan dekat aksesnya menuju pasar tradisional Terminal Baru Subang.

d. Alat atau Sarana

PTD Rumah Potong Hewan Subang Dinas Petemakan dan Kesehatan Hewan Kabupaten Subang belum bisa melengkapi Rumah Potong Hewan dengan perlengkapan yang sesuai dengan standar yang ditetapkan oleh Menteri Pertanian tersebut dikarenakan belum adanya pengajuan anggaran dari Dinas Petemakan Kabupaten Subang untuk merenopasi Rumah Potong Hewan, sehingga UPTD Rumah Potong Hewan Subang Dinas Petemakan dan Kesehatan Hewan Kabupaten Subang masih mempergunakan peralatan yang 
lama yang belum sesuai dengan standar yang telah ditetapkan oleh pemerintah.

e. Kompetensi

Kompetensi pegawai di UPTD .Rumah Potong Hewan Subang Dinas Petemakan dan Kesehatan Hewan Kabupaten Subang masih belum sesuai dengan kompetensi yang seharusnya dimiliki oleh pegawai Rumah Potong Hewan, karena pegawai tersebut bukan dari latar belakang pendidikan Dokter Hewan, tetapi dari tenaga teknis yang diberi pelatihan, dan tidak adanya Dokter Hewan yang bertugas tetap di Rumah Potong Hewan ini, serta petugas yang memotong hewan temak merupakan pegawai tidak tetap yang dibayar sesuai dengan jumlah hewan yang dipotong,

f. Motif

PTD Rumah Potong hewan (RPH) Dinas Peternakan Kabupaten Subang untuk dapat meningatkan motivasi kerja anggotanya berupaya memberikan tanggung jawab, karena tanggung jawab merupakan kesanggupan seseorang untuk menyelesaikan pekerjaan yang diserahkan kepadanya dengan sebaikbaiknya tepat pada waktunya serta berani memikul resiko atas keputusan yang di ambilnya atau tindakan yang dilakukannya. Pemberian penghargaan kepada anggota.

g. Peluang

Kebutuhan daging tersebut tidak dapat terpenuhi oleh Rumah Potong Hewan hal tersebut karena adanya penurunan jumlah pemotongan setiap malamnya dimana biasanya semalam dapat memotong 10 sampai dengan 15 ekor, tetapi sekarang hanya 5 sampai dengan 8 ekor.

2. Fakior-faktor apa yang menghambat pencapaian Kinerja UPTD Rumah Potong Hewan (RPH) Subang pada Dinas Petemakan Kabupaten Subang

a. Pelayanan yang diberikan oleh Rumah Potong hewan masih belum sesuai dengan sasaran yang ingin dicapai, karena Rumah Potong Hewan belum memiliki Dokter Hewan tetap sehingga tidak dapat mengawasi atau memeriksa hewan yang akan dipotong setiap saat, peralatan yang digunakan sudah tidak sesuai dengan persyaratan Rumah Potong Hewan, dan para pemotong hewan bukan pegawai tetap melainkan pegawai harian lepas yang system gajinya berdasarkun jumlah hewan yang di potong.

b. Faktor yang menghambat untuk menciptakan standar kualitas pelayanan yang diberikan kepada pengguna jasa rumah potong hewan adalah faktor sarana prasaran yang sudah tidak mendukung dan sudah tidak sesuai dengan standar SN1 tentang rumah potong hewan No. 01-6159-1999 dan Peraturan Menteri Pertanian Nomor 13/Permentan/01.140/1/2010 tentang Persyaratan Rumah Potong Hewan dan Unit Penanganan Daging dikarenakan faktor anggaran yang belum terealisasi untuk merelokasi rumah potong hewan.

c. Kompetensi pegawai masih sangat kuiang, para petugas pemotong temak merupakan karyawan harian lepas sehingga mereka tidak ada keterikatan dengan Rumah Potong Hewan, dan untuk tenaga Dokler Hewan juga tidak 
ada yang bertugas secara tetap tetapi dokter tersebut bertugas bergilir ke setiap Rumah Potong Hewan yang dikelola oleh Pemerimah melalui Dinas Peternakan Kabupaten Subang.

d. Motivasi pegawai dalam pelaksanaan pelayanan masih kurang, karena mereka kurang mendapat dukungan dari pemerintah daerah, karena para pegawai kebanyakan statusnya masih sukarelawan, dan pegawai harian lepas.

\section{Referensi}

Bagong, Suyanto, 2005. Metode Penelitian Sosial: Berbagai Alternatif Pendekatan.Jakarta : Prenada Media.

Bastian, Indra, 2001. Akuntansi Sektor Publik di Indonesia, Cetakan pertama, Yogyakarta, BPFE.

Dwiyanto, Agus. 2002, Mewujudkan good Governance Melalui Pelayanan Publik, Yogyakarta : UGM Press.

Effendy Marihot Tua, 2002. Manajemen Sumber Daya Manusia. Jakarta Grasindo.

Foster, Bob.2001. Manajemen Ritel. Bandung : Alfabeta.

Indrawijaya. 2006. Perilaku Organisasi. Jakarta : Sinar Baru.

Keban, Yeremias T, 2005, 2005, Enam Dimensi Strategis Administrasi Publik

:Konsep, Teori dan Isu, Yogyakarta : Penerbit gaya Media.

Mangkunegara, A.A Anwar Prabu. 2009.Manajemen Sumber Daya Manusia Bandung : PT Remaja Rosdakarya.

Moleong, Lexy, 2000, Metodologi Penelitian Kualitatif, Bandung : PT. REmaja Rosada Karya.

Sedarmayanti, 2001, Sumber Daya Manusia dan Produktifitas Kerja,Bandung : Mandar Maju.

Wibowo, 2010, Manajemen Kinerja. Jakarta. Penerbit : Rajagrafindo Persada.

Agus Dwiyanto, 2006, Reformasi Birokrasi Publik. Yogyakarta. Gajah Mada University Press.

Dr. Surya Dharma, MPA, 2013, Manajemen Kinerja. Yogyakarta. Pustaka Pelajar.

Paul Hersey, Kenneth H. Balnchard, 1990. Manajemen Prilaku Organisasi.Jakarta. Erlangga.

Peraturan Daerah Kabupaten Subang Nomor 6 Tahun 2012, Tentang Retribusi jasa Usaha.

Peraturan Bupati Subang Nomor 14G.13 Tahun 2008, Tentang Tugas Pokok dan Fungsi Unit Pelaksana Teknis Dias Rumah Potong Hewan dan Rumah Potong Unggas Dinas Peternakan Kabupaten Subang.

SK Menteri Pertanian No: 555/Kpts/TN.240/1986, Tentang Syarat-syarat Rumah Potong Hewan dan Usaha Pemotongan Hewan. 